\title{
Effects of administering testosterone undecanoate in rats subjected to physical exercise: effects on the estrous cycle, motor behavior and morphology of the liver and kidney
}

\author{
Moisés Tolentino Bento-Silva ${ }^{1,3, *}$, Maria do Carmo de Carvalho e Martins ${ }^{2}$, Francisco Leonardo \\ Torres-Leal $^{1,3}$, Talvany Luiz Barros ${ }^{3}$, Ingrid Lara do Nascimento Ferreira de Carvalho ${ }^{2}$, Hugo \\ Aparecido Carvalho Filho², Fernanda Regina de Castro Almeida ${ }^{3}$
}

\author{
${ }^{1}$ Department of Physical Education, Federal University of Piaui, ${ }^{2}$ Department of Physiology and Biophysics, Federal \\ University of Piaui, ${ }^{3}$ Medicinal Plants Research Center, Federal University of Piaui
}

\begin{abstract}
The aim of the work was evaluate the effects of testosterone undecanoate (TU) treatment combined with moderate physical training on: the estrous cycle, body weight (BW), motor behavior (MB), and the morphohistology of the reproductive system, the liver and kidney in rats. Female Wistar rats $(180 \mathrm{~g}$ - $250 \mathrm{~g})$ were divided as follows: sedentary $+\mathrm{TU}(\mathrm{S}+\mathrm{TU})$, trained $+\mathrm{TU}(\mathrm{T}+\mathrm{TU})$, sedentary + vehicle $(\mathrm{S}+\mathrm{V})$, trained + vehicle $(\mathrm{T}+\mathrm{V})$. The rats swam $50 \mathrm{~min} /$ Day, strapped with a $5 \% \mathrm{BW}$ load, for 4 weeks. During this training, (BW) was monitored daily as well as the estrous cycle (EC) by vaginal smear. The TU (15 mg/kg s.c) was administered 3 times/week for 4 weeks. At the end of the study, data on MB, BW and morphohistopathological changes in viscera were compiled. The (T $+\mathrm{TU})$ group had on average, a higher (BW) in the fourth week compared to the first week, and (BW) higher than $(\mathrm{S}+\mathrm{V})$ and $(\mathrm{S}+\mathrm{TU})$ groups. We noted an interruption in the EC and a decrease in weight of ovaries in animals treated with TU. In addition, there was an increase in the relative weight of the heart in groups $(T+V)$ and $(T+T U)$, and kidneys in group $(\mathrm{T}+\mathrm{TU})$. Histopathological analysis showed periportal congestion and isolated foci of hepatic necrosis in rats with TU. Thus, TU combined with training abolished the EC, promoted ovarian atrophy, liver necrosis, cardiac hypertrophy and a decrease in motor activity.
\end{abstract}

Uniterms: Androgenic anabolic steroids/experimental study. Endurance training. Testosterone undecanoate.

\begin{abstract}
O objetivo do trabalho foi avaliar o efeito do tratamento com undecanoato de testosterona (UT) combinado ao treinamento físico moderado sobre ciclo estral, peso corporal, estruturas do sistema reprodutor, comportamento motor e morfologia hepática e renal em ratas. Ratas Wistar (180 a $250 \mathrm{~g}$ ) foram divididas em: sedentárias + UT $(\mathrm{S}+\mathrm{UT})$, treinadas + UT $(\mathrm{T}+\mathrm{UT})$, sedentárias + veículo $(\mathrm{S}+\mathrm{V})$, treinadas + veículo $(\mathrm{T}+\mathrm{V})$. As ratas nadaram $50 \mathrm{~min} /$ dia com sobrecarga de $\sim 5 \%$ do peso corporal por 4 semanas. Durante o período de treinamento foi realizado acompanhamento diário do peso corporal (PC) e do ciclo estral (CE) pelo esfregaço vaginal. O UT (15 mg/kg s.c.) foi administrado $3 \mathrm{x} /$ semana durante 4 semanas. Ao final foram avaliados comportamento motor, pesos e alterações histopatológicas de alguns órgãos. $\mathrm{O}$ grupo $\mathrm{T}+\mathrm{UT}$ apresentou PC maior na quarta semana do que na primeira, com pesos corporais maiores que os grupos $\mathrm{S}+\mathrm{V}$ e $\mathrm{S}+\mathrm{UT}$. Houve interrupção no $\mathrm{CE}$ e redução do peso dos ovários nos animais tratados com UT. Houve aumento do peso relativo do coração, nos grupos T+V e T+UT, e do peso relativo dos rins, no grupo T+UT. A análise histopatológica revelou congestão periportal e focos isolados de necrose hepática nas ratas com UT. O UT combinado com treinamento produziu supressão do ciclo estral, atrofia ovariana, necrose hepática, hipertrofia cardíaca e redução da atividade motora.
\end{abstract}

Unitermos: Esteróides androgênicos anabólicos/estudo experimental. Exercício físico. Undecanoato de testosterona.

\footnotetext{
*Correspondence: M. T. Bento-Silva. Departamento de Educação Física, Universidade Federal do Piauí, Campus Petronio Portela, s/n - 64049-550 -

Teresina - PI, Brasil. E-mail: moisesfisio@yahoo.com.br
} 


\section{INTRODUCTION}

Several studies have emphasized the need for physical exercise programs in promoting global health, due to the positive effect which an active lifestyle has in maintaining health, preventing and reducing the number of chronic non-communicable diseases, besides promoting the quality of life (Matsudo, 2006). On the other hand, the professional athletes always seek to break existing records, which often leads to the use of banned substances such as anabolic androgenic steroids (AAS). In an attempt to magnify the results obtained from physical training, athletes and non-athletes use AAS as ergogenic resources to improve performance and physical appearance (increased muscle mass and tonus) (Perssinen et al., 2002; Maravel et al., 2005; Bahrke et al., 2004; Franke et al., 1997). These steroids (AAS) are synthetic or natural compounds, similar to testosterone, which act directly upon specific types of receptors (Maravel et al., 2005; Clarkson et al., 1997), modulating inseparably both anabolic and androgenic effects (Perssinen et al., 2002; Rabkin et al., 2000; Nasrollah et al., 2001). Currently, over 60 different types of AAS are available for use, varying largely in chemical structure.

The use of anabolic androgenic steroids (AAS) has been the focus of research worldwide, since the administration of AAS is often associated with various adverse dose-related effects, the most common of which are: masculinization in women and children, hypertension, atherosclerosis, thrombosis, jaundice, cancer and liver cancer, tendon injury, as well as psychiatric and behavioral disorders in both sexes (Maravel et al., 2005). Bahrke et al. (2004), report infertility and gynecomastia in men, as well as liver problems, impotence and hypertrophy of the clitoris in women.

Several clinically used substances can often be employed to improve athletic performance, as is the case of Testosterone Undecanoate (TU), clinically prescribed for hormone replacement therapy in men. Several prevalent studies on non-prescribable AAS have shown that such use is not restricted to men (Thiblin et al., 2005; Mobin et al., 2007). However, physiological and behavioral effects of AAS are not well understood in women (Clark et al., 1998).

Although they can be used therapeutically at low doses to treat aplastic anemia (Velazquez et al., 2004), osteoporosis (Berning et al., 2001; Kilbourne et al., 2007), and as antitumor agents in breast cancer (von Bueren et al., 2007) in women, the beneficial health effects of such doses contrast with the risks associated with excessive self-administered doses by women athletes.

Despite the large number of studies involving AAS use, few associate such use with aerobic or endurance exercise among the female population. Cadore et al. (2008) studied the concentrations of total testosterone, free testosterone and cortisol in individuals who trained or otherwise. He noted that home values were similarly increased after the training protocol. Another fact reported in the literature refers to the possibility of AAS use, associated with resistance exercise, reducing the effectiveness of sleep (Venancio et al., 2008). Furthermore, Lambert et al. (1995), studying the effect of AAS treatment on the running performance of rats, found that animals treated with AAS and subjected to physical training of moderate intensity showed an increase in resistance of $41 \%$ compared to the group that received saline, while no changes were detected in the sedentary groups.

Considering the frequent use of AAS and their potential health risks, coupled with few studies assessing the effects of these drugs in females, the objective of this study was to evaluate the effect of Testosterone Undecanoate treatment (TU) in rats subjected to swimming in term of: body weight, structures of the reproductive system, the estrous cycle, motor activity, and histopathological changes of heart, liver and kidneys.

\section{METHODS}

\section{Animals}

Experiments were performed on adult female rats $(\mathrm{N}=32)$ of the Wistar strain, weighing (180-250 g), obtained from the laboratory of Research on Medicinal Plants, Federal University of Piauí. The animals were kept in Bollman cages, each housing four animals with controlled room temperature and a light-dark $12 / 12 \mathrm{~h}$ cycle and free access to water and food. All procedures complied with the ethical standards set by the Brazilian College of Animal Experimentation.

\section{Treatment}

The animals were randomly assigned to four groups, each comprising eight animals: sedentary treated with TU, trained treated with TU, vehicle-treated sedentary and trained but treated with vehicle. Each respective group received the Vehicle or AAS, by a subcutaneous injection of vegetable oil $(0.1 \mathrm{~mL} / 100 \mathrm{~g} /$ body weight $)$ or testosterone undecanoate (Androxon ${ }^{\circledR} 15 \mathrm{mg} / \mathrm{kg}$ ), 3x/week for 4 weeks (Lindqvist et al., 2005).

\section{Physical training}

The training protocol was adapted from Medeiros et 
al. (2004), where the rats in the trained groups were submitted to a $50 \mathrm{~min} /$ day swim in a rectangular cylinder with water at $28 \pm 1{ }^{\circ} \mathrm{C}$ ( 5 days/week), for a period of 4 weeks. After the adaptation period to the water, the rats received increasing burdens in the form of load weights attached to their backs up to the study end-point of 4 weeks, making up $5 \%$ of body weight.

\section{Evaluation of motor exploratory behavior (open field)}

At the end of the training and treatment, the rats were submitted to an exploratory motor capacity evaluation (open field) (Burghardt et al., 2004), viewing the feasibility of its application. The test consisted of placing the rats at the center of a square arena $(25 \times 75 \times 75 \mathrm{~cm})$ divided into nine parts of equal size. To assess exploratory locomotor ability, the number of invasions each rat made by crossing to another square on four legs during a 5-minute period was quantified.

\section{Monitoring the estrous cycle}

During the administration of testosterone undecanoate and physical training we monitored the estrous cycle of the animals in all groups, on a daily basis between 17:00hs and 18:00hs, by determining the cell types and characteristics in fresh colorless vaginal washes observed under a light microscope. These characteristics were categorized as: a) the proestrous phase, consisting of nucleated cells, b) estrous phase, consisting of cornified epithelial cells, c) metestrous, consisting of white blood cells in combination with cornified epithelial cells, and d) diestrous phase, consisting of isolated (or grouped) leukocytes and nucleated cells (Thrower et al., 1981).

\section{Evaluation of weight of tissues: uterus, ovary, liver, kidneys and heart}

At the end of the 4 weeks of treatment and training, the rats were euthanized under anesthesia with inhaled ether, causing pneumothorax, and tissues verified by making a midline incision up to the sternal level, opening the thoracic cavity and rupturing the diaphragm. The uterus, ovaries, liver, kidneys and heart were carefully collected and weighed.

\section{Histological processing and evaluation of liver, kidneys and heart}

Sorted fragments of liver, kidneys and heart were immersed in a solution of $10 \%$ formalin for histological processing, and fixed in paraffin. The blocks were cut into $7 \mathrm{~mm}$-thick slices and stained with hematoxylin-eosin for histological analysis. Histological evaluation took into account the presence of changes such as: 1) inflammatory response, 2) periportal hepatic congestion, with foci of hepatic necrosis, 3) hyaline sclerosis in renal arterioles and kidney degeneration (common in intense physically active), and 4) presence of changes in the thickness of walls and signs of hypertrophy of myocardial fibers.

\section{Statistical analysis}

Data were presented as mean \pm SEM and analyzed by a paired $t$ test to compare differences within groups, and analysis of variance (ANOVA one way) followed by post-hoc test (Tukey) for comparison between groups. The level of significance was set at $\mathrm{p}<0.05$. The pathological examinations were compared between the groups using the Chi-square test $(\chi 2)$, and a significance level of $p<0.05$.

\section{RESULTS}

The assessment of body weight showed no significant difference between the initial weights of the four groups during the first week of training and/or treatment (Figure 1). With regard to the weight of the animals on the fourth week, there was a significant increase in body weight of the trained group treated with TU, compared to the sedentary groups with or without treatment with TU $(\mathrm{p}<0.05)$. The gain in weight during training and/or treatment was noticeable in the trained group treated with $\mathrm{TU}$,

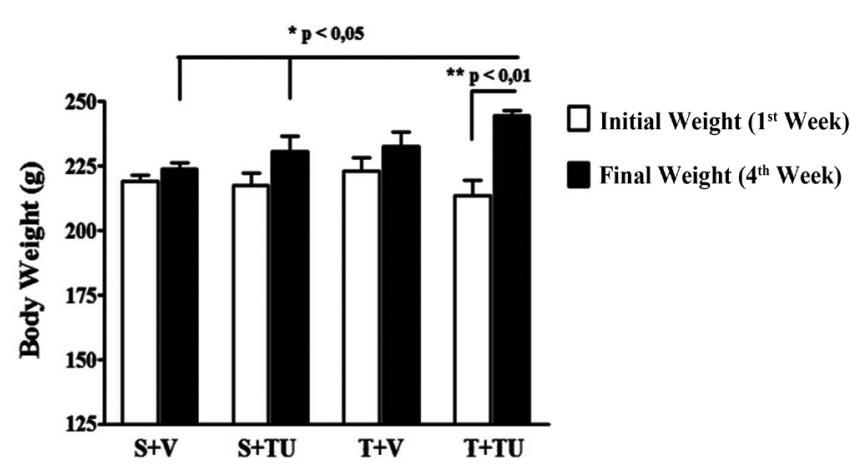

FIGURE 1 - Effect of treating sedentary (S) or trained (T) rats with Testosterone Undecanoate (TU) (15 mg.kg s.c) or Vehicle (V) on body weight $(\mathrm{g})$. The (T) group was submitted to swimming exercise training for 4 weeks $(* p<0.05$ as for the T+TU group on the fourth week, we conducted one-way (ANOVA) followed by Tukey post-hoc, $* * \mathrm{p}<0.01$ paired t test on final weight compared to baseline within the group). The data are expressed as mean \pm SEM of 8 animals per group. 
TABLE I - Effect of Testosterone Undecanoate (TU) (15 mg.kg s.c) or Vehicle (oil) treatment on the estrous cycle of sedentary rats or animals subjected to physical training by swimming for 4 weeks

\begin{tabular}{lcccccc}
\hline & $\begin{array}{c}\text { Number of } \\
\text { cycles per rats }\end{array}$ & $\begin{array}{c}\text { Duration of the } \\
\text { cycles (days) }\end{array}$ & \multicolumn{3}{c}{ Duration of each phase in the cycle (days) } \\
\hline Groups $(\mathrm{n}=8)$ & & & Estrus & Metestrus & Diestrus & Proestrus \\
\hline Sedentary & $4.00 \pm 0.00$ & $5.40 \pm 0.13$ & $1.3 \pm 0.2$ & $1.14 \pm 0.17$ & $2.08 \pm 0.28$ & $0.80 \pm 0.11$ \\
Trained & $4.12 \pm 0.64$ & $5.24 \pm 0.54$ & $2.4 \pm 0.2$ & $1.10 \pm 0.14$ & $2.09 \pm 0.15$ & $0.86 \pm 0.11$ \\
Sedentary + TU & 0 & 0 & 0 & $0.12 \pm 0.35$ & $21.88 \pm 0.35$ & 0 \\
Trained + TU & 0 & 0 & 0 & 0 & $22.00 \pm 0.00^{*}$ & 0 \\
\hline
\end{tabular}

The data are expressed as (mean \pm SEM of $\mathrm{n}=8$ rats/group).

* Animals were anestrous throughout the treatment period.

which showed significant weight gain between the first and fourth weeks of training $(\mathrm{p}<0.01)$.

On monitoring the vaginal cytology daily (for 4 weeks), we observed that treatment with TU altered the estrous cycle by interrupting the estrous (the animals were actually anestrus) both in the sedentary and trained group. Moreover, physical training through swimming for 4 weeks produced no change in either the number or duration of estrous cycles (Table I).

Concerning the corrected weights ( $\mathrm{g} / 100 \mathrm{~g}$ body weight) of reproductive organs, although no changes were observed in the uterus (Figure 2), the data showed an approximate $50 \%$ reduction in ovaries of animal groups treated with TU compared to those of animals treated with vehicle $(\mathrm{p}<0.001)$ (Figure 3).

Figure 4 evidences an increase in cardiac mass $(\mathrm{p}<0.01)$ in trained groups with/without $\mathrm{TU}(0.37 \pm 0.01$ and $0.41 \pm 0.01 \mathrm{~g}$, respectively). There were no significant differences in the corrected weights of livers among the 4

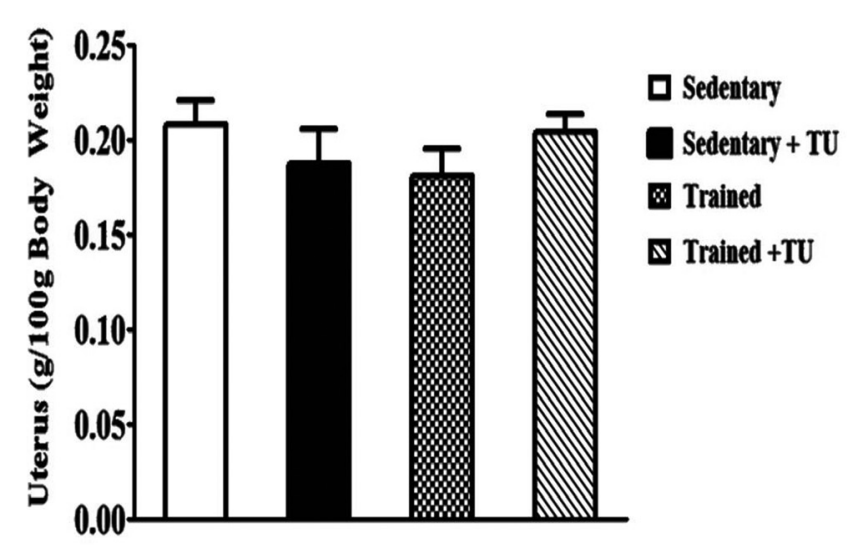

FIGURE 2 - Effect of Testosterone Undecanoate (TU) (15 mg.kg s.c) or Vehicle (oil) treatment on the uterine weights corrected for body weight $(\mathrm{g} / 100 \mathrm{~g})$ in sedentary and trained rats submitted to swimming exercise training for 4 weeks. The data are expressed as mean \pm SEM of 8 animals/group. animal groups $(3.1 \pm 0.13,3.0 \pm 0.17,3.2 \pm 0.12$ and $3.6 \pm$ $0.30 \mathrm{~g}$, respectively), as shown in Figure 5. In Table II, the analysis shows periportal hepatic congestion $(p<0.05)$ in $62.5 \%$ of animals in the trained group treated with TU and in $50 \%$ of the animals from the sedentary group treated with TU, and foci of liver necrosis (isolated without an inflammatory response) in $62.5 \%$ of the groups (trained and sedentary) treated with TU.

The results of the weight of the kidneys, as shown in Figure 6, revealed no significant differences in corrected weights between the sedentary groups with/without administration of TU, and trained groups without TU $(0.64 \pm 0.02,0.65 \pm 0.01$ and $0.64 \pm 0.02 \mathrm{~g}$ respectively $)$. However, the weight of the kidneys of the trained group treated with TU was significantly higher than the other 3 groups $(0.71 \pm 0.01 \mathrm{~g}, \mathrm{p}<0.05)$. Moreover, morphological changes characterized by degeneration of the kidney were

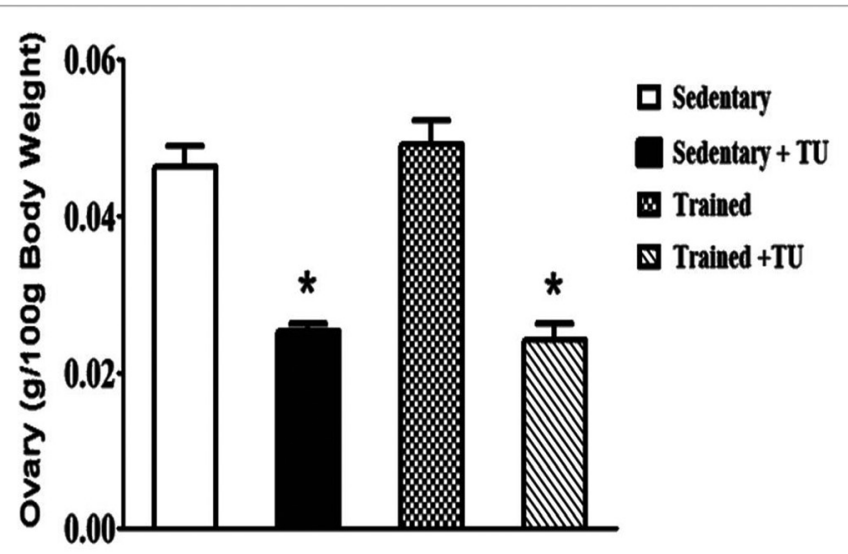

FIGURE 3 - Effect of Testosterone Undecanoate (TU) (15 mg.kg s.c) or Vehicle (oil) treatment on the weight of ovaries corrected for body weight $(\mathrm{g} / 100 \mathrm{~g})$ in sedentary or trained rats submitted to swimming exercise training for 4 weeks. The data are expressed as mean \pm SEM $(n=8)$ followed by ANOVA and post-hoc. $* \mathrm{P}<0.05$ between test groups Sedentary $+\mathrm{TU} v s$ Sedentary and Trained + TU vs Trained. 


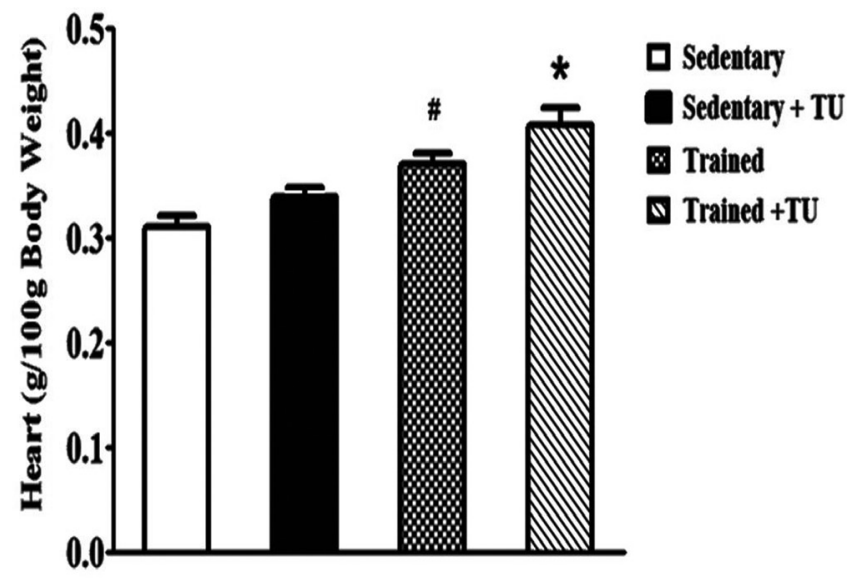

FIGURE 4 - Effect of testosterone undecanoate (TU) (15 mg.kg s.c) or Vehicle (oil) treatment on the heart weight corrected for body weight $(\mathrm{g} / 100 \mathrm{~g})$ in sedentary or trained rats submitted to swimming exercise training for 4 weeks. The data are expressed as mean \pm SEM $(n=8)$ followed by ANOVA and post-hoc. (\# $\mathrm{p}<0.05$ Sedentary $v s$ Trained and $* \mathrm{p}<0.05$ for Trained $+\mathrm{TU}$ vs Sedentary and Sedentary $+\mathrm{TU})$.

found in $25 \%$ of the animals in the trained group treated with TU, and $37.5 \%$ of the trained group without TU.

Figure 7 presents the results of exploratory motor activity on the open field test. There were no significant differences between the sedentary + vehicle and trained + vehicle $(33.8 \pm 13.0$ vs $46.6 \pm 16.8$ invasions - Figure 7A) or between the sedentary + vehicle and sedentary + TU (33.8 \pm 13.0 vs. $24.0 \pm 11.6$ invasions - Figure 7B). However, the trained + TU group showed a significant decrease $(\mathrm{p}<0.05)$ in exploratory motor activity compared to the trained + vehicle group $(26.16 \pm 12.79$ vs $46.6 \pm$ 16.80 invasions - Figure 7C).

\section{DISCUSSION}

Treating rats with testosterone undecanoate associa-

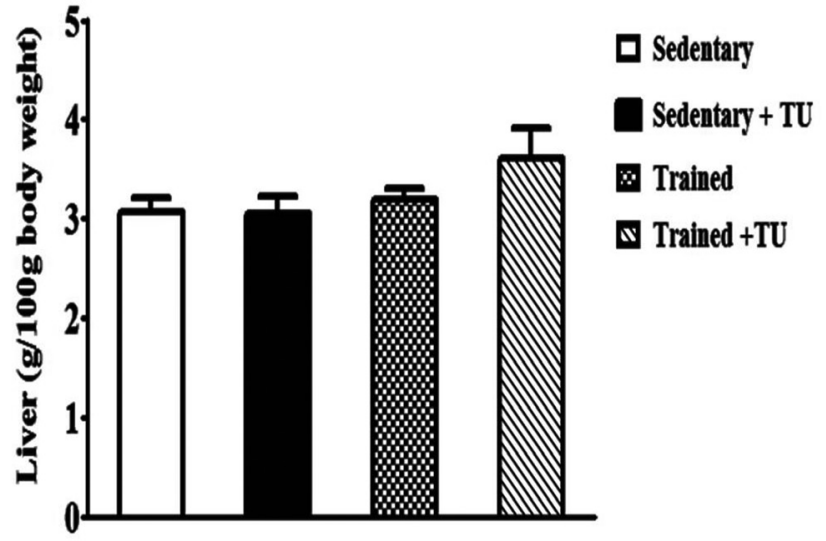

FIGURE 5 - Effect of Testosterone Undecanoate (TU) (15 mg.kg s.c) or Vehicle (oil) treatment on liver weight corrected for body weight $(\mathrm{g} / 100 \mathrm{~g})$ in sedentary or trained rats submitted to swimming exercise training for 4 weeks.

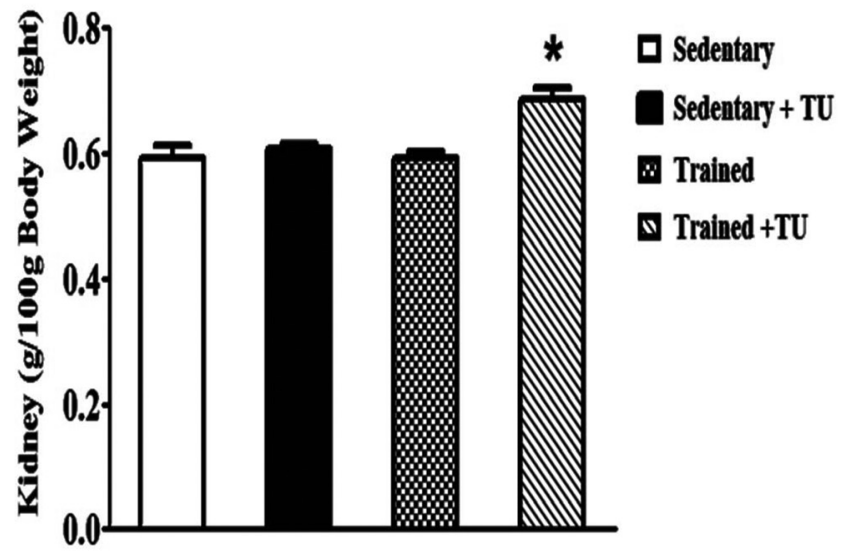

FIGURE 6 - Effect of testosterone undecanoate (TU) (15 mg.kg s.c) or Vehicle (oil) treatment on kidney weight corrected for body weight $(\mathrm{g} / 100 \mathrm{~g})$ in sedentary or trained rats submitted to swimming exercise training for 4 weeks. The data are expressed as mean $\pm \operatorname{SEM}(\mathrm{n}=8)$ followed by ANOVA and post-hoc. ${ }^{*} \mathrm{p}$ $<0.05$, Trained + TU vs Sedentary, Sedentary + TU and Trained.

TABLE II - Histopathological changes found in the liver and kidneys of rats treated with Testosterone Undecanoate (TU) (15 mg.kg s.c) or Vehicle (oil), with and/or without swimming exercise training for 4 weeks

\begin{tabular}{lcccccc}
\hline & \multicolumn{4}{c}{ Liver } & \multicolumn{2}{c}{ Kidney } \\
\cline { 2 - 6 } Groups $(\mathrm{n}=8)$ & \multicolumn{2}{c}{ Hepatic congestion } & \multicolumn{2}{c}{ Necrosis } & & Number \\
\cline { 2 - 6 } & Number & $\%$ & Number & $\%$ & 0.0 & 0.0 \\
\hline Sedentary & 0 & 0.0 & 0 & $62.5^{*}$ & 0 & 0.0 \\
Sedentary+TU & 4 & $50.0^{*}$ & 5 & 0.0 & 3 & 37.5 \\
Trained & 1 & 12.5 & 0 & $62.5^{\#}$ & 2 & 25.0 \\
Trained+TU & 5 & $62.5^{\#}$ & 5 &
\end{tabular}

$* \mathrm{P}<0.05$, Chi-square test (x2) for Sedentary + TU vs Sedentary.

$\# \mathrm{P}<0.05$, Chi-square test $(\mathrm{x} 2)$ for Trained $+\mathrm{TU}$ vs Trained. 


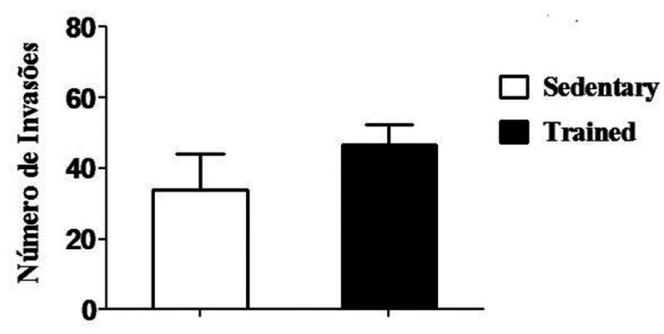

a
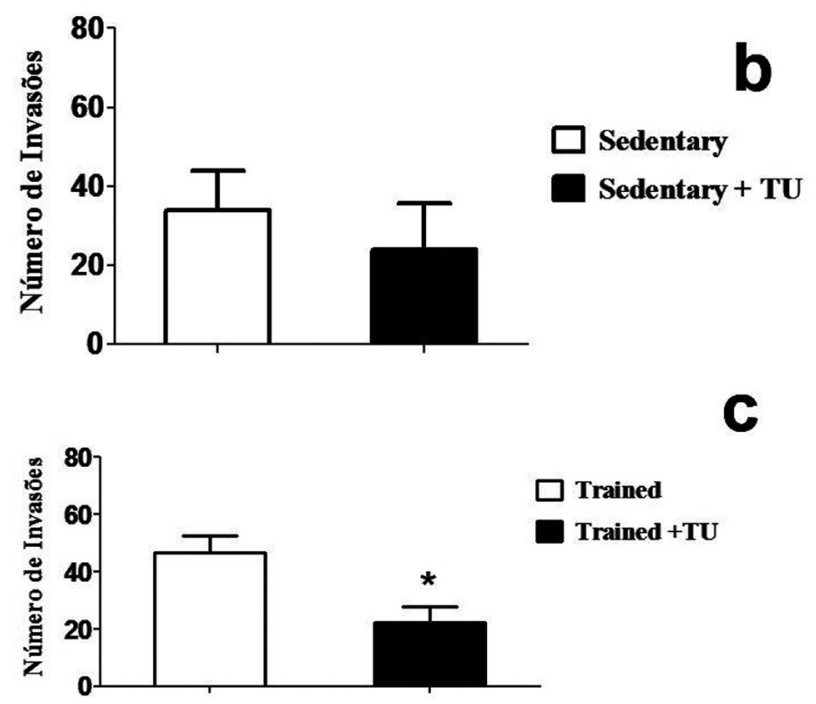

FIGURE 7 - Effect of Testosterone Undecanoate (TU) (15 mg.kg s.c) or Vehicle (oil) treatment on motor activity (open field test) in sedentary and trained rats submitted to swimming exercise training for 4 weeks. The data are expressed as mean \pm SEM $(\mathrm{n}=8)$ followed by ANOVA and post hoc. $* \mathrm{P}<0.05$ Trained + TU vs Trained, box C).

ted with moderate physical training for 4 weeks promoted gain in weight $(\mathrm{p}<0.01)$, which was absent in animals treated with TU but not subjected to the exercise program. Similarly, no significant weight gain was observed in the group which underwent training for 4 weeks without TU. According to Cunha et al. (2005a), AAS treatment promotes a significant decrease in weight in sedentary animals, which does not occur in exercised rats. This finding is explained by the changes occurring in physical training, which by itself is not enhanced by AAS treatment. This in turn is explained by the fact that, at excessive concentrations, AAS can inhibit growth and weight gain due to decreased appetite, electrolyte imbalance and increased lipid oxidation as a result of increased activity of the enzyme carnitine palmitoyltransferase (Lee et al., 2003; Guzman et al., 1991). Another relevant issue is the fact that physical training may provoke exercise-induced anoxia, which is potentially linked to increased blood concentrations of peptide YY, GLP-1 and pancreatic polypeptide PP (Martins et al., 2007).
In an experimental model combining physical training and treatment of rats with AAS, Cunha et al. (2005b) found increased body weight and altered biochemical factors in rats submitted to anaerobic training (leaps) which had been treated for six weeks with Nandrolone Decanoate (DECA). However, in another experimental model using isolated forms of AAS, Blarberg et al. (1997), studying the effects of $17 \alpha$-Methyltestosterone, Methandrostenolone, and Nandrolone Decanoate on the estrous cycle, found no significant body weight change in animals treated with these compounds. Similarly, Clark et al. (1998) found that treating rats with Stanozolol for 2 weeks had no significant effect on body weight during the study period.

Regarding the effects of testosterone undecanoate treatment on the estrous cycle, vaginal cytology manifested distinct alterations, characterized principally by the absence of the estrous phase in all trained and sedentary groups treated with TU. By contrast, the groups of rats which did not receive TU had a positive estrous phase, with each cycle lasting about five days on average. These findings corroborate with the results of other studies which have demonstrated that varied isoforms of AAS disrupt the vaginal cytology cyclical changes. Blasberg et al. (1997) observed that the treatment with $17 \alpha$-methyltestosterone, methandrostenolone, and nandrolone decanoate at doses that mimic those used by human athletes, produced reversible and a dose-dependent sexual receptivity conduct and oestrous vaginal cytology in rats over a two-week period. During the intervening period, these animals manifested lordosis, infrequently accompanied by characteristic diestrous phase smears, and the author also observed that the effects of treating with Nandrolone Decanoate at a dose of $7.5 \mathrm{mg} / \mathrm{kg}$ on the estrous cycle were longer, where vaginal estrous resumed within 2 months of treatment completion.

Regarding the mechanisms involved in these changes, some authors associate the effects of testosterone on the ovaries. In this sense, Clark et al. (1998) suggests that the decrease in time of vaginal estrus during two weeks of treatment with AAS, as well as the absence of estrus (i.e. persistent diestrus) during the recovery period, pronounced with testosterone use, could be related to the existence of different routes of metabolism of the steroid and its relationship to the reproductive function. Triemstra et al. (2004) studied the effects of AAS on the female reproductive system, noting an inhibitory effect. In other studies, where a cessation of vaginal estrus in the presence of high concentrations of testosterone was observed, it was suggested that such a response could possibly result from the degenerative effects of high levels of androgens on ovarian granulosa cells (Anderson, 1989; Anderson et al., 1987). 
Furthermore, the use of AAS leads to impaired function of the hypothalamic-pituitary-gonadal system (HPG), raising the levels of circulating androgens that may reduce the release of gonadotropins through negative feedback which (in females ) decreases the secretion of estrogen (Harlan et al., 1992; Kao et al., 1975; Strauss et al., 1993). According to Bronson (1996), the suppression of LH, FHS and of estradiol and cessation of vaginal cycle in rats are all associated with chronic treatment with AAS.

Eklof et al. (2003) reported that the use of anabolic steroids in males causes decreased levels of luteinizing hormone, follicle-stimulating hormone, as well as a lower production of endogenous testosterone and sperm, leading to testicular atrophy. Moreover, in rats treated with nandrolone decanoate at a dose of $3 \mathrm{mg} / \mathrm{kg}$, the destruction of follicular units and absence of Corpora luteum in the ovaries have been demonstrated, alongside morphological changes in the uterus such as endometrial fibrosis (Gerez et al. 2005). Far et al. (2007) showed that administering nandrolone decanoate at a dose of $15 \mathrm{mg} / \mathrm{kg}$ causes morphological changes in uteri of rats associated with suppression of reproductive capacity. The results of our study corroborate those reported in the literature, in that chronic treatment with TU led to the suppression of the estrous cycle resulting in ovarian atrophy, besides significant reduction of weight, probably due to inhibition of HPG and the effects of testosterone on the female gonads. The weight, structure and the receptors to sex steroids in the uterus were not significantly altered among the studied animals, while some studies have reported no changes with chronic use of AAS.

Aerobic training per se, has proven to be valuable for patients with chronic kidney disease (CKD), promoting an increase in oxygen consumption, while moderately intense exercise programs can lead to improved quality of life in patients with renal failure (Daul et al., 2004; Johansen, 2005). In this study, we observed renal histopathological changes in rats submitted to moderately intense training with vehicle, as well as those trained and treated with TU, suggesting that in this case treatment with steroids may not be interfering with renal morphology. However, intense training combined with AAS, as seen in weightlifters, can cause kidney damage (Rava et al., 2000).

Testosterone and its synthetic derivatives, the AAS, are known to stimulate muscle protein synthesis and enlargement, and recent studies have demonstrated better muscle function recovery after injury (Lynch et al., 2008). However, the use of AAS has adverse effects on the cardiac muscle including disintegration of the functional syncytium, cardiac rupture, deterioration of cardiac function and apoptosis (Appell et al. 1983; Cavasin et al. 2006; Crisostomo et al., 2006).
Associating AAS with aerobic exercise promotes increased deposition of collagen in the heart, causing ventricular remodeling, a phenomenon associated with local activation of the renin-angiotensin system (Rocha et al., 2007). However, treatment with AAS nandrolone for 4 weeks does not promote change in the Bezold-Jarisch reflex, which increases in relation to the efferent vagal pathway (Andrade et al., 2008).

In the present study we observed increase in cardiac mass in both trained groups. However, rats submitted to exercise training and pretreated with $\mathrm{TU}$ presented greater mean heart mass than animals subjected to training alone. Published data indicate that chronic use of AAS is directly related to an increase in number of cardiac myocytes (Marsh et al., 1998). According to Trifunovic et al. (1995, 1998), chronic administration of high doses of anabolic androgenic steroids such as nandrolone decanoate, similar to those used by athletes, attributes to a decrease in compliance of the myocardium in the left ventricle, as well as changes in contractility and cardiac performance. In contrast, AAS administration, combined with physical training, has been reported to prevent cardiac hypertrophy in dogs submitted to endurance training (Moore, 1998).

The cardiac remodeling associated with the use of AAS alters ventricular function, resulting in cardiovascular disease (Woodiwiss et al., 2000; Kasikcioglu et al., 2008). This remodeling induced by physical activity is usually considered beneficial physiologically, because it improves cardiac metabolism, ventricular structure and blood flow (Moore, 1998). Chronic cardiovascular disease due to cardiac remodeling is considered pathological and is characterized by, among others features, changes in cell size and metabolism (Aeschbacher et al., 2001).

In relation to the liver, studies have shown that clinical subchronic treatment with Nandrolone Decanoate at high doses promotes deleterious effects to the liver (Vieira et al., 2008). In our results, although no significant differences in adjusted body weight of the animals was noted, we stress the intense periportal hepatic congestion found in $62.5 \%$ ( 5 rats) of the animals in the trained group treated with TU, and in $50 \%$ of the sedentary group of animals treated with TU. Outbreaks of isolated hepatic necrosis without inflammatory response were also observed in $62.5 \%$ of trained and sedentary groups treated with TU. Absent inflammatory response at analyzed necrotic sites is atypical, since this response represents a physiologic attempt to remove dead cells. The effects of chronic use and abuse of AAS in the liver, serum lipids and the reproductive system are well documented (Hartgens et al., 2004). Accordingly, chronic use of AAS leads to structural and functional changes in the liver such as cholestatic jaundice, 
peliotic hepatic hyperplasia and hepatocellular adenomas (Fortunato et al., 2006). Moreover, Boada et al. (1999) observed that rats treated with high doses of Stanozolol showed inflammation or degeneration of the central lobe of the liver, a change which is proliferant in all hepatocytes.

Burghardt et al. (2004) studied the effects of chronic treadmill training on behavioral parameters in rats and concluded that the exploratory locomotor activity, assessed using the open field method, was reduced after training. As for prolonged use of AAS in females, it was associated with decreased locomotor activity and increased aggression, a finding explained by increased depressive behavior (Bronson et al., 1996). The increase in aggressive behavior was also associated with decreased amount of serotonin (5-HT) in rats that were chronically treated with AAS (Keleti et al., 2007; Kubala et al., 2008). In our study, rats treated with TU associated with physical training showed a decrease in exploratory motor activity, assessed using the open-corroborating data from the literature. However, physical training (or single treatment with $\mathrm{TU}$ ) alone proved unable to promote change in locomotor exploratory behavior.

In conclusion, the chronic use of TU associated with moderately intense physical training for 4 weeks, causes an increase in body weight, as well as increased relative weight of the heart and kidneys. In the liver, TU promoted histological changes ranging from hepatic necrosis to periportal congestion. The reproductive system of rats was altered by chronic use of TU, through interruption of the estrous cycle and ovarian atrophy. TU associated with exercise also reduced exploratory motor activity.

\section{REFERENCES}

ANDRADE, T.U.; SANTOS, M.C.; BUSATO, V.C.; MEDEIROS, A.R.; ABREU, G.R.; MOYSÉS, M.R.; BISSOLI, N.S. Higher physiological doses of nandrolone decanoate do not influence the Bezold-Jarish reflex control of bradycardia. Arch. Med. Res., v.39, n. 1, p.27-32, 2008.

APPELL, H.J.; HELLER-UMPFENBACH, B.; FERAUDI, M.; WEICKER, H. Ultrastructural and morphometric investigations on the effects of training and administration of anabolic steroids on the myocardium of guinea pigs. Int. J. Sports Med., v.4, n. 4, p.268-274, 1983.

ANDERSON, E.; LITTLE, B.; LEE, G.S. Androgen-induced changes in rat ovarian granulosa cells in vitro. Tissue Cell, v. 19, n. 2, p. 217-234, 1987.
ANDERSON, E. In vivo and in vitro effects of androgens on rat ovarian granulosa cells. Am. J. Obstet. Gynecol., v.160, n.4, p.782-788, 1989.

AESCHBACHER, B.; HUTTER, D.; FUHRER, J.; WEIDMANN, P.; DELACRETAZ, E.; ALLEMANN, Y. Diastolic dysfunction precedes myocardial hypertrophy in the development of hypertension. Am. J. Hyper., v.14, n. 2 , p.106-113, 2001.

BAHRKE, M.S.; YESALIS, C.E. Abuse of anabolic androgenic steroids and related substances in sport and exercise. Curr. Opin. Pharmacol., v.4, n.6, p.614-620, 2004.

BREMBER, W.J.; ZHANG, G.Y.; GU, Y.Q.; WAMG, X.H.; CUI, Y. A. Pharmacokinetic study oj injetable testosterone undecanoate in hypogonodal men. J. Androl., v.19, n.6, p.761-768, 1998.

BERNING, B.; BENNINK, H.J.; FAUSER, B.C. Tibolone and its effects on bone: a review. Climacteric, v.4, n. 2, p.12036, 2001.

BRONSON, F.H.; NGUYEN, K.Q.; DE LA ROSA, J. Effect of anabolic steroids on behavior and physiological characteristics of female mice. Physiol. Behav., v.59, n.1, p.49-55, 1996.

BLASBERG, M.E.; LANGAN, C.J.; CLARK, A.S. The effects of 17 alpha-methyltestosterone, methandrostenolone, and nandrolone decanoate on the rat estrous cycle. Physiol. Behav., v.61, n.2, p.265-272, 1997.

BROWMAN, L.G. Effects of androsterone and testosterone on oestrous cycle of rats. Proc. Soc. Exp. Biol. Med., v.36, n. 2, p.205-208, 1937.

BRONSON, F.H. Effects of prolonged exposure to anabolic steroids on the behavior of male and female mice. Pharmacol. Biochem. Behav., v.53, n.2, p.329-334, 1996.

BOADA, L.D.; ZUMBADO, M.; TORRES, S.; LÓPEZ A.; DÍAZ-CHICO, B.N.; CABRERA, J.J.; LUZARDO, O.P. Evaluation of acute and chronic hepatotoxic effects exerted by anabolic-androgenic steroid stanozolol in adult male rats. Arch. Toxicol., v.73, n.8-9, p.465-472, 1999.

BURGHARDT, P.R.; FULK, L.J.; HAND, G.A.; WILSON, M.A. The effects of chronic treadmill and wheel running on behavior in rats. Brain Res., v.3, n.1-2, p.84-96, 2004. 
CAVASIN, M.A.; TAO, Z.Y.; YU, A.L.; YANG, X.P. Testosterone enhances early cardiac remodeling after myocardial infarction, causing rupture and degrading cardiac function. Am. J. Physiol. Heart Circ. Physiol., v.290, n.5, p.2043-2050, 2006.

CLARKSON, P.M.; THOMPSON, H.S. Drugs and sport. Research findings and limitations. Sports Med., v.24, n.6, p.366-384, 1997.

CRISOSTOMO, P.R.; WANG, M.; WAIRIUKO, G.M.; MORRELL, E.D.; MELDRUM, D.R. Brief exposure to exogenous testosterone increases death signaling and adversely affects myocardial function after ischemia. Am. J. Physiol. Regul. Integr. Comp. Physiol., v.290, n.5, p.11681174, 2006.

CUNHA, T.S.; TANNO, A.P.; MOURA, M.J.C.S.; MARCONDES F.K. Relação entre a administração de esteróide anabólico androgênico, treinamento físico aeróbio e supercompensação do glicogênio. Rev. Bras. Med. Esporte, v.11, n.3, p.187-192, 2005.

CUNHA, T.S.; TANNO, A.P.; MOURA, M.J.C.S.; MARCONDES, F.K. Influence of high-intensity exercise training and anabolic androgenic steroid treatment on rat tissue glycogen content. Life Sci., v.77, n.9, p.1030-1043, 2005.

CLARK, A.S.; BLASBERG, M.E.; BRANDLING-BENNETT, E.M. Stanozolol, oxymetholone, and testosterone cypionate effects on the rat estrous cycle. Physiol. Behav., v.63, n.2, p.287-295, 1998.

DAUL, A.E.; SCHÄFERS, R.F.; DAUL, K.; PHILIPP, T. Exercise during hemodialysis. Clin. Nephrol., v.61, n.1, p.26-30, 2004.

EKLOF, A.C.; THURELIUS, A.M.; GARLE, M.; RANE, A.; SJOQVIST, F. The anti-doping hot-line a means to capture the abuse of doping agents in the Swedish society and a new service function in clinical pharmacology. Eur. J. Clin. Pharmacol., v.59, n.8-9, p.571-577, 2003.

FRANKE, W.W.; BERENDONK, B. Hormonal doping and androgenization of athletes: a secret program of the German Democratic Republic government. Clin. Chem., v.43, n.7, p.1262-1279, 1997.
FAR, H.R.M.; GREN, G.A.; LINDQVIST,A.S.; MARMENTAL, M.; FAHLKE, C.; THIBLIN, I. Administration of the anabolic androgenic steroid nandrolone decanoate to female rats causes alterations in the morphology of their uterus and a reduction in reproductive capacity. Eur. J. Obstet. Gynecol. Reprod. Biol., v.131, n.2, p.189-197, 2007.

FORTUNATO, R.S.; MARASSI, M.P.; CHAVES, E.A.; NASCIMENTO, J.H.; ROSENTHAL, D.; CARVALHO, D.P. Chronic administration of anabolic androgenic steroid alters murine thyroid function. Med. Sci. Sports Exerc. v.38, n.2, p.256-261, 2006.

GEREZ, J.R.; FREI, F.; CAMARGO, I.C.C. Histological assessment of ovaries and uterus of rats subjected to nandrolone decanoate treatment. Contraception, v.72, n.1, p.77-80, 2005.

GUZMAN, M,; SABORIDO, A.; CASTRO, J.; MOLANO, F.; MEGIAS, A. Treatment with anabolic steroids increases the activity of the mitochondrial outer carnitin palmitoyltransferase in rat liver and fast-twitch muscle. Biochem. Pharm., v.41, n.5, p.833-835, 1991.

HARTGENS, F.; RIETJENS, G.; KEIZER, H.A.; KUIPERS, H.; WOLFFENBUTTEL, B.H. Effects of androgenic-anabolic steroids on apolipoproteins and lipoprotein (a). Br. J. Sports Med., v.38, n.5, p.253-259, 2004.

HARLAN, R.E.; GARCIA, M.M. Neurobiology of androgen abuse. In: WATSON, R. R. (Ed.). Drugs of abuse and neurobiology. New York: CRC Press, 1992. p.185-207.

HONG, J.H.; AHN, T.Y. Oral testosterone replacement in korean patients with PADAM. Aging Male, v.5, n.1, p.52-56, 2002.

JOHANSEN, K.L. Exercise and chronic kidney disease: current recommendations. Sports Med., v.35, n. ,6, p.485-499, 2005.

KASIKCIOGLU, E.; OFLAZ, H.; UMMAN, B.; BUGRA, Z. Androgenic anabolic steroids also impair right ventricular function. Int. J. Cardiol., v.134, n.1, p.123-125, 2009.

KAO, L.W.L.; WEISZ, J. Direct effect of testosterone and its 5alpha-reduced metabolites on pituitary LH and FSH release in vitro: change in pituitary responsiveness to hypothalamic extract. Endocrinology, v.96, n.2, p.253-260, 1975.

KELETA, Y.B.; LUMIA, A.R.; ANDERSON, G.M.; MCGINNIS, M.Y. Behavioral effects of pubertal anabolic androgenic steroid exposure in male rats with low serotonin. Brain Res., v.1132, n.1, p.129-138, 2007. 
KILBOURNE, E.J.; MOORE, W.J.; FREEDMAN, L.P.; NAGPAL, S. Selective androgen receptor modulators for frailty and osteoporosis. Curr. Opin. Investig. Drugs, v.8, n.10, p.821-829, 2007.

KUBALA, K.H.; MCGINNIS, M.Y.; ANDERSON, G.M.; LUMIA, A.R. The effects of an anabolic androgenic steroid and low serotonin on social and non-social behaviors in male rats. Brain Res., v.1232, n.26, p.21-29, 2008.

LEE, W.J.; MCCLUNG, J.; HAND, G.A.; CARSON, J.A. Overload-induced androgen receptor expression in the aged rat hindlimb receiving nandrolone decanoate. J. Appl. Physiol., v.94, n.3, p.1153-1161, 2003.

LINDQVIST, A.S.; FAHLKE, C. Nandrolone decanoate has long-term effects on dominance in a competitive situation in male rats. Physiol. Behav., v.84, n.1, p.45-51, 2005.

LYNCH, G.S.; SCHERTZER, J.D.; RYALL, J.G. Anabolic agents for improving muscle regeneration and function after injury. Clin. Exp. Pharmacol. Physiol., v.35, n.7, p.852-858, 2008.

MARSH JD, LEHMANN MH, RITCHIE RH, GWATHMEY JK, GREEN GE, SCHIE-BINGER RJ. Androgen receptors mediate hypertrophy in cardiac myocytes. Circulation, v.98, n.3, p.256-261, 1998.

MARTINS, C.; MORGAN, L.M.; BLOOM, S.R.; ROBERTSON, M.D. Effects of exercise on gut peptides, energy intake and appetite. J. Endocrinol., v.193, n.2, p.251-258, 2007.

MARAVELIAS, C.; DONA, A.; STEFANIDOU, M.; SPILIOPOULOU, C. Adverse effects of anabolic steroids in athletes A constant threat. Toxicol. Lett., v.158, n.3, p.167-175, 2005.

MATSUDO, S.M. Atividade física na promoção da saúde e qualidade de vida no envelhecimento. Rev. Bras. Educ. Fís. Esp., v.20, suppl.5, p.135-137, 2006.

MEDEIROS, A.; OLIVEIRA, E.M.; NEGRÃO, C.E.; BRUM, P.C. Swimming Training increases cardiac vagal activity and induces cardiac hypertrophy in rats. Braz. J. Med. Biol. Res., v.37, n.12, p.1909-1917, 2004.

MOORE, R. Cellular adaptations of the heart muscle to exercise training. Ann. Med., v.30, suppl.1, p.46-53, 1998.
MOBINI FAR, H.R.; AGREN, G.; LINDQVIST, A.S.; MARMENDAL, M.; FAHLKE, C.; THIBLIN, I. Administration of the anabolic androgenic steroid nandrolone decanoate to female rats causes alterations in the morphology of their uterus and a reduction in reproductive capacity. Eur. J. Obstet. Gynecol. Reprod. Biol., v.131, n.2, p.189-197, 2007.

NASROLLAH, T.S. A Review of the Chemistry, Biological Action, and Clinical Applications of Anabolic-Androgenic Steroids. Clin. Ther, v.23, n.9, p.1355-1390, 2001.

PARSSINEN, M.; SEPPALA, T. Steroid use and long-term health risks in former athletes. Sports Med., v.32, n.2, p.83-94, 2002.

RABKIN, J.G.; WAGNER, G.J.; RABKIN, R. A double-blind, placebo-controlled trial of testosterone therapy for HIVpositive men with hypogonadal symptoms. Arch. Gen. Pscych., v.57, n.2, p.141-147, 2000.

REVAI, T.; SAPI, Z.; BENEDEK, S.; KOVACS, A.; KASZAS, I.; VIRANYI, M.; WINKLER, G. Severe nephrotic syndrome in a young man taking anabolic steroid and creatine long term. Orv. Hetil., v.144, n.49, p.2425-2427, 2000.

ROCHA, F.L.; CARMO, E.C.; ROQUE, F.R.; HASHIMOTO, N.Y.; ROSSONI, L.V.; FRIMM, C.; ANÉAS, I.; NEGRÃO, C.E.; KRIEGER, J.E.; OLIVEIRA, E.M. Anabolic steroids induce cardiac renin-angiotensin system and impair the beneficial effects of aerobic training in rats. Am. J. Physiol. Heart Circ. Physiol., v.293, n.6, p.3575-3583, 2007.

SCHUBERT, M.; MINNEMANN, T.; BLER, D.H.; ROUSKOVA, D., CHRISTOPH, A.; OETTEL, M.; ERNST, M.; MELLINGER, U.; KRONE, W.; JOCKENHOVEL, F. A. Intramuscular Testosterone Undecanoate: Pharmacokinetic Aspects of a Novel Testosterone Formulation during LongTerm Treatment of Men with Hypogonadism. J. Clin. Endocrinol. Metab., v.89, n.11, p.5429-5434, 2004.

STRAUSS, R.H.; YESALIS, C.E. Additional effects of anabolic steroids on women. In: YESALIS, C.E. (Ed.). Anabolic steroids in sport and exercise. Champaign: Human Kinetics Publishers, Inc., 1993. p.151-160.

TAKALA, T.E.; RAMO, P.; KIVILUOMA, K.; VIHKO, V.; KAINULAINEN, H.; KETTUNEN, R. Effects of training and anabolic steroids on collagen synthesis in dog heart. Eur. J. Appl. Physiol. Occup. Physiol., v.62, n.1, p.1-6, 1991. 
THROWER, S.; LIM, L. The nuclear oestrogen receptor in the female rat. Effects of oestradiol administration during the oestrous cycle on the uterus and contrasting effects of progesterone on the uterus and hypothalamus. Biochem. J., v.198, n.2, p.385-389, 1981.

THIBLIN, I.; PETERSSON, A. Pharmacoepidemiology of anabolic androgenic steroids: a review. Fundam. Clin. Pharmacol., v.19, n.1, p.27-44, 2005.

TRIFUNOVIC, B.; NORTON, G.R.; DUFFIELD, M.J.; AVRAAMP, P.; WOODWISS, A.J. An androgenic steroid decreases left ventricular compliance in rats. Am. J. Physiol., v.268, p.H1096-1105, 1995.

TRIFUNOVIC, B.; WOODIWISS, A.J.; DUFFIELD, M.; NORTON, G.R. Novel attributes of an androgenic steroidmediated increase in cardiac end diastolic stiffness in rats. Can. J. Physiol. Pharmacol., v.268, n.3(Pt 2), p.657-664, 1998.

TRIEMSTRA, J.L.; WOOD, R.I. Testosterone selfadministration in female hamsters. Behav. Brain Res., v.154, n.1, p.221-229, 2004.
VAN ZYL, C.G.; NOAKES, T.D.; LAMBERT, M.I. Anabolicandrogenic steroid increases running endurance in rats. Med. Sci. Sports Exerc., v.27, n.10, p.1385-1389, 1995.

VELAZQUEZ, I.; ALTER, B.P. Androgens and liver tumors: Fanconi's anemia and non-Fanconi's conditions. Am. J. Hematol., v.77, n.3, p.257-267, 2004.

VIEIRA, R.P.; FRANÇA, R.F.; DAMACENO-RODRIGUES, N.R.; DOLHNIKOFF, M.; CALDINI, E.G.; CARVALHO, C.R.; RIBEIRO, W. Dose-dependent hepatic response to subchronic administration of nandrolone decanoate. Med. Sci. Sports Exerc., v.40, n.5, p.842-847, 2008.

VON BUEREN, A.O.; MA, R.; SCHLUMPF, M.; LICHTENSTEIGER, W. Salbutamol exhibits androgenic activity in vitro. Br. J. Sports Med., v.41, n.12, p.874-878, 2007.

WOODIWISS, A.J.; TRIFUNOVIC, B.; PHILIPPIDES, M.; NORTON, G.R. Effects of an androgenic steroid on exercise-induced cardiac remodeling in rats. J. Appl. Physiol., v.88, n.2, p.409-415, 2000.

Received for publication on $23^{\text {th }}$ July 2008 Accepted for publication on $25^{\text {th }}$ August 2009 
